\title{
SESAME VARIETAL RESPONSE TO MICROELEMENTS FOLIAR APPLICATION AND SOIL N FERTILIZATION IN LOAMY SAND \\ SOIL
}

\author{
Salah M. Emam
}

Agron. Dept., Fac., Agric., Fayoum Univ., Egypt.

\begin{abstract}
Two field experiments were carried out at the experimental farm of the Faculty of Agriculture, Fayoum University, Egypt during 2013 and 2014 summer seasons to study the effect of microelements foliar application and nitrogen fertilization levels on growth, yield and yield components of two sesame (Sesamum indicum L.) verities, i.e., $\mathrm{V}_{1}$ : Shandaweel 3 and $\mathrm{V}_{2}$ : Sohag 1. A split split-plot arrangement in randomize complete block design with four replications was used in both seasons. Two nitrogen fertilization levels, i.e., $\mathrm{N}_{1}$ : 40 and $\mathrm{N}_{2}: 60 \mathrm{~kg} \mathrm{~N}^{-1}$ fed allocated in the sub-plots and with three microelement rates, i.e., $\mathrm{M}_{1}: 200, \mathrm{M}_{2}: 300$ and $\mathrm{M}_{3}: 400 \mathrm{~g} \mathrm{fed}^{-1}$ (were dissolved in 200L water $\mathrm{fed}^{-1}$ ) distributed in the sub sub-plot, while varieties occupied the main plots. The microelement were added in form of EDTA (Fe 7.5\%, Mn 3.5\%, Zn $0.70 \%, \mathrm{Cu} 0.28 \%$, B $0.65 \%$ and Mo $0.30 \%$ w/w). The obtained results showed that Sohag 1 significantly surpassed Shandaweel 3 in growth parameters (i.e., plant height, stem diameter and number of capsules plant $^{-1}$ ) as well as yield and yield components (i.e., capsules weight plant ${ }^{-1}$, seed yield plant ${ }^{-1}$, seed, oil and biological yields $\mathrm{fed}^{-1}$, harvest index and oil $\%$. The $\mathrm{N}$ rate of $60 \mathrm{~kg} \mathrm{fed}^{-1}$ significantly exceed the rate of $40 \mathrm{~kg} \mathrm{fed}^{-1}$ over the two seasons. Microelement foliar application at $400 \mathrm{~g} \mathrm{fed}^{-1}$ gave significantly the highest values for all traits over the two seasons as compared to 200 and $300 \mathrm{~g} \mathrm{fed}^{-1}$.
\end{abstract}

Key words: Sesame, Verities, N levels, Microelements.

INTRODUCTION

Sesame (Sesamum indicum L.), otherwise known as sesamum or benniseed, member of the family Pedaliaceae, is one of the most ancient oilseeds crop known to mankind. It is an important oil seed crop of the warm region of the tropics and sub-tropics. Sesame plays an important role in human nutrition. Most of the sesame seeds is used for oil extraction and the rest is used for edible purposes (El Khier et al., 2008). The moisture, crude protein, ash, fat, fiber, total carbohydrate, $\mathrm{Ca}, \mathrm{Zn}$ and $\mathrm{Fe}$ were ranged: 3.17-3.96, 22.5824.27, 4.46-6.19, 50.88-52.67, 5.60-6.26, 8.3-11.69, 1172.08-1225.71 mg/100g, 4.23- $4.45 \mathrm{mg} / 100 \mathrm{~g}$ and 10.2-10.75 mg/100g, respectively (Zebib et al., 2015).

Sesame is grown in many parts of the world on over 5 million acres $\left(20,000 \mathrm{~km}^{2}\right)$. The largest producers of the crop in 2007 was India, China, Myanmar, Sudan, Ethiopia, Uganda and Nigeria. The sesame cultivated area all over the world in 2013 was 9416368.86 ha. Africa occupies the first place among the continents in the cultivated area by 4793131 ha and Asia have the next place by 4341601.25 ha. Also, Africa have 54.66\% from total world seed yield (FAO, 2015).

Fayoum J. Agric. Res. \& Dev., Vol. 29, No.1, January, 2015 
In Egypt, sesame is considering a food rather than oilseed crop, because most of its seeds are directly consumed. Total area under sesame production in Egypt has decreased from 41214, in 2011 to 24639, by 2013 while, the productivity increased from $578 \mathrm{~kg} \mathrm{fed}^{-1}$ in 2011 to $586 \mathrm{~kg} \mathrm{fed}^{-1}$ in 2013 (Bulletin Agricultural Statistics, 2013 and 2014). Low cultivated area and production of sesame is attributed to the fact that the crop is usually grown in less fertile soils. Further, lack of proper nutrient management is one of the major causes for low yield (Purushottam, 2005).

Improved and high yielding cultivars of sesame can give more yield than traditional ones. Chen et al. (1994) mentioned that sesame cultivar Zhong Zhi 9 outyielded the control cultivar Wulinghei by $32.9 \%$ but showed yield potential and adaptability similar to $c v$. Zhong Zhi 7. Similarly, Shinde et al., (1994) found that new sesame cultivar Padma gave 14, 28 and 34\% more seed yields than those of Tapi, TC-25 and Phule Til-1, respectively. Iorlamen et al., (2014) showed that varieties had no significant effect on plant height, stem diameter and number of capsules plant ${ }^{-1}$. On the other hand, in Egypt, Osman (1993) reported that sesame genotypes varied in yield and yield components as well as in response to nitrogen application. El-Habbasha et al.(2007) found that the varietal differences between the two varieties of sesame (Giza 32 and Shandaweel 3) in plant height, number of capsules plant ${ }^{-1}$, seed weight plant $^{-1}$ and 1000-seed weight were not significant except plant height where, Shandawel 3 surpassed Giza 32. While, Giza 32 variety surpassed in 1000-seed weight. However, Kassab et al. (2012) stated that shandweel 3 variety gave the highest plant height, number of capsules plant ${ }^{-1}$ and weight of capsules plant ${ }^{-1}$ as compared to Giza 32 and Toshky1 varieties.

Nitrogen is a component of protoplasm, proteins, nucleic acids, chlorophyll and plays a vital role both in vegetative and reproductive phase of crop growth. Sesame has been recognized as a heavy feeder and uses more nitrogen than any other nutrient element. The $\mathrm{N}$ fertilizer is considered one of the most important factors to increase crop yields per unit area. $\mathrm{N}$ application to sesame has been reported to increase plant height, stem diameter, number of capsules plant $^{-1}$, 1000-seed weight, biological, seed and oil yields, (Malik et al., 1990; Sinharoy et al., 1990; Jadhav et al., 1992; Pawar et al., 1993; Ishwar et al., 1994; Mankar et al., 1995; Sharar et al., 2000; El-Habbasha et al., 2007; El-Nakhlawy and Shaheen 2009; Shehu et al., 2010; Noorka et al., 2011; Boghdady et al., 2012; Jouyban and Moosavi 2012 and Blal et al., 2013). On the other hand, seed oil content was reduced by increasing $\mathrm{N}$ application (Sharar et al., 2000; El-Habbasha et al., 2007; Noorka et al., 2011). While, Boghdady et al. (2012) mentioned that the treatment of $100 \%$ from the recommended dose of mineral fertilizers NP did not statistically differ from that of $50 \%$ of the recommended dose of NP plus biofertilizers in their effect. Blal et al. (2013) found that increasing $\mathrm{N}$ fertilization up to 40 $\mathrm{kg} /$ feddan+seryalin significantly increased 1000-seed weight, number of capsules plant ${ }^{-1}$, capsules weight, seed yield plant ${ }^{-1}$ and Oil \%. However, increasing $\mathrm{N}$ application to $60 \mathrm{~kg} / \mathrm{feddan}+$ seryalin reduced all these traits.

Fayoum J. Agric. Res. \& Dev., Vol. 29, No.1, January, 2015 
SESAME VARIETAL RESPONSE TO MICROELEMENTS.

Foliar application of nutrients has became an efficient way to increase yield and quality of crops (Romemheld and El-Fouly, 1999). Spraying sesame plants with boron (B) solutions improved their growth and yields (Hamideldin and Hussein 2014). Heidari et al.(2011) found that iron fertilizer had significant effect on sesame seed yield. Abid et al. (2006) mentioned that 1000grain weight and grain yield of rice increased significantly with the application of $\mathrm{Zn}, \mathrm{Fe}$ and $\mathrm{Mn}$ alone or in various combinations. Results obtained by Zeidan et al. (2010) on wheat, indicated that grain yield, straw yield and 1000-grain weight were significantly increased by foliar application of $\mathrm{Fe}, \mathrm{Mn}$ and $\mathrm{Zn}$. Using of micronutrients, foliar application, caused yield improvement of safflower (Kohnaward et al., 2012).

Therefore, the present research was designed to study the effect of mineral nitrogen rates and microelements foliar application on growth, yield and yield components as well as seed oil percentage of two sesame varieties in loamy sand soils.

\section{MATERIALS AND METHODS}

Two field experiments were carried out at the experimental farm of the Faculty of Agriculture, Fayoum University, south east Fayoum $\left(29^{\circ} 17^{\prime} \mathrm{N} ; 30^{\circ}\right.$ 53'E) Egypt, during 2013 and 2014 summer seasons. It aimed to study the effect of nitrogen fertilization levels and microelements rates on plant growth, yield components, seed yield and seed oil percentage of two sesame varieties, i.e., $\mathrm{V}_{1}$ : Shandaweel 3 and $\mathrm{V}_{2}$ : Sohag 1 . Two nitrogen fertilization levels, i.e., $\mathrm{N}_{1}$ : 40 and $\mathrm{N}_{2}: 60 \mathrm{~kg} \mathrm{~N}^{-1} \mathrm{fed}^{-1}$ (as ammonium nitrate $33.5 \% \mathrm{~N}$ ) were combined with three microelement rates, i.e., $\mathrm{M}_{1}: 200, \mathrm{M}_{2}: 300$ and $\mathrm{M}_{3}: 400 \mathrm{~g} \mathrm{fed}^{-1}$ (dissolved in $200 \mathrm{~L}$ water $\mathrm{fed}^{-1}$ ) were tested. The microelement were added in form of EDTA (Fe 7.5\%, Mn 3.5\%, Zn 0.70\%, Cu 0.28\%, B $0.65 \%$ and Mo $0.30 \%$ $\mathrm{w} / \mathrm{w})$ in three equal doses with the first, second and third irrigation. The split split-plot arrangement in randomize complete block design with four replicates was used, where sesame varieties occupied the main plots, nitrogen fertilization levels treatments allocated to the sub-plots and microelements rates were distributed in sub sub-plots. The sub sub-plots area was $10.5 \mathrm{~m}^{2}(3 \times 3.5 \mathrm{~m}$ equal 1/400 feddan) consisted of five rows. Varieties were obtained from the Oil Crops Research Section, Field Crop Research Institute, Agricultural Research Centre, Giza, Egypt. Sesame seeds (Shandaweel 3 and Sohag 1 cvs.) at the rate of $4 \mathrm{~kg} \mathrm{fed}^{-1}$ were sown on June $3^{\text {rd }}$ and $5^{\text {th }}$ in the first and second seasons, respectively. Seeds were sown at hills $10 \mathrm{~cm}$ apart. At the $1^{\text {st }}$ irrigation, the plants were thinned to be one plants hill ${ }^{-1}$. Calcium super phosphate $\left(15.5 \mathrm{P}_{2} \mathrm{O}_{5}\right)$ at rate of $200 \mathrm{~kg} \mathrm{fed}^{-1}$ was added during soil preparation and $50 \mathrm{~kg} \mathrm{fed}^{-1}$ potassium sulphate $\left(48 \% \mathrm{~K}_{2} \mathrm{O}\right)$ with the second irrigation were added. Nitrogen fertilization was applied in three equal doses at the $1^{\text {st }}, 2^{\text {nd }}$ and $3^{\text {rd }}$ irrigations. All other recommended agricultural practices for sesame production were adopted throughout the growing seasons; 2013 and 2014 according to the bulletin of Egyptian Ministry of Agriculture (1018/2006). Soil physical and chemical properties of the experimental site were determined according to Wilde et al. (1985) and presented in Table (1).

Fayoum J. Agric. Res. \& Dev., Vol. 29, No.1, January, 2015 
At harvesting time, random sample of 10 guarded plants was taken from each sub sub-plot to determine the growth traits, i.e., Plant height $(\mathrm{cm})$, stem diameter $(\mathrm{cm})$ and number of capsules plant ${ }^{-1}$. The weight of capsules plant $^{-1}(\mathrm{~g})$, seed yield plant ${ }^{-1}(\mathrm{~g}), 1000$ - seed weight $(\mathrm{g})$, biological yield $(\mathrm{kg})$ fed $^{-}$ ${ }_{1}^{1}$, seed yield $(\mathrm{kg}) \mathrm{fed}^{-1}$, oil yield $(\mathrm{kg})$ fed $^{-1}$, harvest index were recorded from each sub sub-plot. In addition, Seed oil content $(\%)$ that determined by using Soxhelt extraction apparatus using petroleum ether as a solvent and then the seed oil percentage was calculated on dry weight basis according to A.O.A.C (1990). All the measurements and collected data were subjected to the statistical analysis as described by Snedecor and Cochran (1990).

Table (1): Physical and chemical properties of the experimental soil in the two growing summer seasons 2013 and 2014.

\begin{tabular}{|c|c|c|}
\hline Properties & 2013 & 2014 \\
\hline \multicolumn{3}{|c|}{ Physical properties: } \\
\hline Sand $\%$ & 75.64 & 76.46 \\
\hline Silt \% & 12.43 & 11.87 \\
\hline Clay \% & 11.93 & 11.67 \\
\hline Texture class & Loamy sand & Loamy sand \\
\hline \multicolumn{3}{|c|}{ Chemical properties: } \\
\hline $\mathrm{Ec}_{\mathrm{e}} \mathrm{dS} \mathrm{m}^{-1}$ & 3.56 & 3.64 \\
\hline $\mathrm{pH}$ & 7.34 & 7.52 \\
\hline Organic matter \% & 0.83 & 0.76 \\
\hline Total N $\quad(\%)$ & 0.078 & 0.071 \\
\hline Available $\mathrm{P}$ (ppm) & 6.54 & 5.86 \\
\hline Available $\mathrm{K}$ (ppm) & 146 & 143 \\
\hline
\end{tabular}

\section{RESULTS AND DISCUSSION}

\section{I- Growth parameters:}

The effect of $\mathrm{N}$ levels and micronutrient on sesame varieties and the interactions among them on some growth parameters are presented in Table (2).

The results cleared that Sohag $1 c v$ significantly surpassed Shandaweel $3 c v$. Averages of Sohag 1 variety for plant height, stem diameter and number of capsules plnat ${ }^{-1}$ were higher by $28.68,20.22$ and $44.10 \%$ than Shandaweel 3 variety, respectively in the first season. The same trend was observed in the second season for plant height. While, stem diameter and number of capsules plant $^{-1}$ were non significantly differed between the two cultivars. These results support those obtained by Sharar et al., 2000 and Noorka et al., 2011. On the other hand, El-Habbasha et al. (2007) mentioned that the differences between Shandaweel 3 and Giza 32 were non significant for number of capsules plant ${ }^{-1}$. Also, the results obtained by Iorlamen et al. (2014) showed that varieties tested by them had no significant differences for plant height, stem diameter and number of capsules plant ${ }^{-1}$.

Data recorded in Table (2) indicate that increasing the level of nitrogen fertilization significantly affected plant height and stem diameter. Number of

Fayoum J. Agric. Res. \& Dev., Vol. 29, No.1, January, 2015 
capsules plant ${ }^{-1}$ showed insignificant effect in the two successive seasons. Increasing $\mathrm{N}$ levels from 40 to $60 \mathrm{~kg} \mathrm{~N}^{-1}$ caused significant increases in plant height and stem diameter in the first season by 9.74 and $11.83 \%$, respectively, and in the second one by 15.13 and $17.87 \%$, respectively. These increments may be due to the role of nitrogen in stimulating amino acid building and growth hormones, which in turn acts positively cell division and enlargement. These results are in the same trend with those obtained by Malik et al. (1990); Sinharoy et al. (1990); Jadhav et al. (1992); Pawar et al. (1993); Ishwar et al. (1994); Mankar et al. (1995); Sharar et al. (2000); ElNakhlawy and Shaheen (2009); Shehu et al. (2010); Noorka et al. (2011); Boghdady et al. (2012); Jouyban and Moosavi (2012) and Blal et al. (2013). While, El-Habbasha et al.(2007) applied NPK fertilizers and organic farmyard manure, and found that fertilizers had no significant effect on plant height and number of capsules plant ${ }^{-1}$

Table (2 ): Effect of microelement foliar application and $\mathrm{N}$ levels on some growth parameters of two sesame varieties in the two seasons.

\begin{tabular}{|c|c|c|c|c|c|c|c|}
\hline \multicolumn{2}{|c|}{ Treatments } & $\begin{array}{l}\text { Plant } \\
\text { height } \\
(\mathbf{c m})\end{array}$ & $\begin{array}{c}\text { Stem } \\
\text { diameter } \\
(\mathrm{cm})\end{array}$ & $\begin{array}{c}\text { No. of } \\
\text { capsules } \\
\text { Plant }^{-1}\end{array}$ & $\begin{array}{c}\text { Plant } \\
\text { height } \\
(\mathrm{cm})\end{array}$ & $\begin{array}{c}\text { Stem } \\
\text { diameter } \\
(\mathrm{cm})\end{array}$ & $\begin{array}{c}\text { No. of } \\
\text { capsules } \\
\text { Plant }^{-1}\end{array}$ \\
\hline & & \multicolumn{3}{|c|}{2013 season } & \multicolumn{3}{|c|}{2014 season } \\
\hline \multirow{2}{*}{$\begin{array}{l}\text { Varieties } \\
\text { (A) }\end{array}$} & Shandaweel 3 & 120.68 & 0.89 & 58.86 & 118.50 & 0.84 & 55.94 \\
\hline & Sohag 1 & 155.22 & 1.07 & 84.82 & 153.58 & 0.99 & 75.50 \\
\hline \multicolumn{2}{|c|}{$\mathbf{L S D}_{\mathbf{a}}$} & $10.22 * *$ & $0.05 * *$ & $24.18^{*}$ & $1.50 * *$ & NS & NS \\
\hline \multirow{3}{*}{$\begin{array}{l}\text { N levels } \\
\text { (B) } \\
\end{array}$} & $40 \mathrm{~kg} \mathrm{fed}^{-1}$ & 131.54 & 0.93 & 65.47 & 126.47 & 0.84 & 59.42 \\
\hline & $60 \mathrm{~kg} \mathrm{fed}^{-1}$ & 144.36 & 1.04 & 78.21 & 145.61 & 0.99 & 72.03 \\
\hline & $\mathbf{S D}_{\mathrm{b}}$ & 9.80* & $0.04 * *$ & NS & $4.10 * *$ & $0.07 * *$ & NS \\
\hline \multirow{3}{*}{$\begin{array}{l}\text { Micro } \\
\text { Elements } \\
\text { (c) }\end{array}$} & $200 \mathrm{~g} \mathrm{fed}^{-1}$ & 127.64 & 0.85 & 52.25 & 124.08 & 0.77 & 50.20 \\
\hline & $300 \mathrm{~g} \mathrm{fed}^{-1}$ & 137.21 & 0.99 & 70.29 & 134.71 & 0.93 & 67.38 \\
\hline & $400 \mathrm{~g} \mathrm{fed}^{-1}$ & 149.00 & 1.10 & 92.98 & 149.33 & 1.05 & 79.58 \\
\hline \multicolumn{2}{|c|}{ LSDc } & $2.12 *$ & $0.02 * *$ & $7.39 * *$ & $2.62 * *$ & $0.04 * *$ & $5.90 * *$ \\
\hline \multirow{4}{*}{ Interactions } & $\mathbf{A B}$ & NS & NS & NS & $* *$ & NS & NS \\
\hline & $\mathbf{A C}$ & $* *$ & NS & $* *$ & $*$ & NS & $*$ \\
\hline & BC & $* *$ & $* *$ & NS & $* *$ & NS & NS \\
\hline & $\mathbf{A B C}$ & NS & NS & NS & $* *$ & NS & NS \\
\hline
\end{tabular}

Results in Table (2) revealed that applying $400 \mathrm{~g} \mathrm{fed}^{-1}$ gave the highest averages of all growth parameters in both seasons. Increasing microelements rate from 200 to $400 \mathrm{~g} \mathrm{fed}^{-1}$ led to increase the plant height, stem diameter and number of capsules plant ${ }^{-1}$ by $16.73,29.41$ and $77.95 \%$, respectively in 2013 season, and by $20.35,36.36$ and $58.53 \%$, respectively in 2014 season. Such finding can be attributed to the positive role of these nutrients in the metabolic processes that take place inside the plant and its importance in the formation and multiplying meristem cells and stimulate growth buds and form new branches. Besides that the role of foliar fertilization by zinc and iron on the

Fayoum J. Agric. Res. \& Dev., Vol. 29, No.1, January, 2015 
activity of reproductive cells. Adding of these nutrients will lead to the activity of the vaccinatum tubes and then increase the number of fertile flowers that result in more number of capsules formed. These results are in agreement with those obtained by Romemheld and El-Fouly (1999); Abid et al. (2006); Zeidan et al. (2010); Heidari et al. (2011); Kohnaward et al. (2012); Hamideldin and Hussein (2014) and Mahdi (2014).

Results in Table (2) show that the interaction between the tested treatment on growth parameters was differed according to specific interact treatments. The interact between varieties and nitrogen levels was not significant in the both seasons except its effects on plant height in 2014 season. On the other hands, the interaction between varieties and microelements foliar application rates had a significant effect on plant height and number of capsules plant $^{-1}$ in both seasons, whereas, there was insignificant effect on stem diameter in the two successive seasons. Likewise, the interaction between nitrogen fertilization levels and the rates of microelements foliar application had insignificant effect on growth parameters in the $1^{\text {st }}$ and $2^{\text {nd }}$ seasons except plant height in the two successive seasons and stem diameter in first one. Results revealed that insignificant effect by the triple interaction among the treatments $(\mathrm{ABC})$ in first and second seasons except plant height in the second season. ElHabbasha et al. (2007) found no significant effect between varieties and fertilization on plant height and number of capsules plant ${ }^{-1}$, while El-Nakhlawy and Shaheen (2009) stated that interaction between varieties and $\mathrm{N}$ fertilizer was significant on the same parameters. The same trend was observed by Amanullah et al., (2014) and Iarlamen et al. (2014).

II-Yield and yield components.

Results in Table (3) indicate that the variety Sohag 1 gave the highest averages and significant for all yield and its components traits compared with Shandawel $3 c v$ in both seasons. Whereas, there were no significant differences between the two varieties in biological yield $\mathrm{fed}^{-1}$ in the first season and seed index in both successive seasons. These results confirm the findings of Osman et al. (1993), Shinde et al. (1994), El-Habbasha et al. (2007), Kassab et al. (2012), Amanullah et al. (2014) and Iarlamen et al. (2014).

Regarding the effect of $\mathrm{N}$ fertilization levels, data presented in Table (3) show that increasing the $\mathrm{N}$ fertilization levels from 40 to $60 \mathrm{~kg} \mathrm{~N}^{\mathrm{N}} \mathrm{fed}^{-1}$ hadn't significant effect on biological yield in first season as well as capsules weight plant $^{-1}$, seed yield plant ${ }^{-1}$ and harvest index in the second one. Conversely, the increasing of $\mathrm{N}$ fertilization levels from 40 to $60 \mathrm{~kg} \mathrm{~N}^{\mathrm{N}} \mathrm{f}^{-1}$, significantly increased capsules weight, seed yield plant ${ }^{-1}$, seed yield fed ${ }^{-1}$, oil yield fed $^{-1}$, harvest index and seed index by 22.55, 19.34. 10.72, 8.50, 5.87 and 9.27\%, respectively in 2013 season. In 2014 season, the significant increases percentage in seed yield $\mathrm{fed}^{-1}$, biological yield $\mathrm{fed}^{-1}$, oil yield $\mathrm{fed}^{-1}$ and seed index were 8.65, 7.08, 6.45 and $9.64 \%$, respectively. On other hand, increasing the $\mathrm{N}$ fertilization levels had the reverse effect on oil \%, as it reduced the oil percentage in 2013 season by $2.09 \%$ and in 2014 season by $2.02 \%$. These results are in agreement with those found by Sharar et al. (2000); El-

Fayoum J. Agric. Res. \& Dev., Vol. 29, No.1, January, 2015 
SESAME VARIETAL RESPONSE TO MICROELEMENTS

Habbasha et al. (2007); Shehu et al.(2010); Noorka et al. (2011); Jakusko and Usman (2013), Amanullah et al. (2014) and Iarlamen et al. (2014).

Concerning the effect of micronutrients foliar application rates, results indicated that sesame yield and its components were significantly affected by microelements treatments in both seasons. Applying $400 \mathrm{~g} \mathrm{fed}^{-1}$ gave the highest averages of yield and its components, while applying $200 \mathrm{~g} \mathrm{fed}^{-1}$ gave the lowest ones in both seasons. Increasing the rate of microelements foliar application from 300 to $400 \mathrm{~g} \mathrm{fed}^{-1}$ significantly increased the yield and its components, i.e., capsules weight plant ${ }^{-1}$, seed yield plant ${ }^{-1}$, seed yield $\mathrm{fed}^{-1}$, oil yield fed $^{-1}$, harvest index and oil $\%$, by $24.72,30.59,16.18,8.96,17.62,6.92$, 4.61 and $1.22 \%$, respectively, in 2013 season, and by $20.00,22.83,12.80,6.84$, $14.47,5.66,4.80$ and $1.52 \%$, respectively, in 2014 season. It could be concluded that increasing microelements foliar application rate from 200 to 300 or $400 \mathrm{~g} \mathrm{fed}^{-1}$ significantly increased sesame yield and its components.

Table (3): Effect of microelement foliar application and $\mathbf{N}$ levels on some growth parameters of two sesame varieties.

\begin{tabular}{|c|c|c|c|c|c|c|c|c|c|}
\hline Trea & itments & $\begin{array}{c}\text { Capsules } \\
\text { weight } \\
\text { plant }^{-1}\end{array}$ & $\begin{array}{c}\text { Seed } \\
\text { yield g } \\
\text { plant }^{-1}\end{array}$ & $\begin{array}{c}\text { Seed } \\
\text { yield } \\
\text { kg fed }^{-1}\end{array}$ & $\begin{array}{l}\text { Biological } \\
\text { Yield } \\
\text { Kg fed }^{-1}\end{array}$ & $\begin{array}{c}\text { Oil } \\
\text { yield } \\
\text { kg fed }^{-1}\end{array}$ & $\begin{array}{c}\text { Harvest } \\
\text { index }\end{array}$ & $\begin{array}{c}\text { Seed } \\
\text { index }\end{array}$ & $\begin{array}{l}\text { Oil } \\
\%\end{array}$ \\
\hline \multicolumn{10}{|c|}{2013 season } \\
\hline \multirow{2}{*}{$\begin{array}{l}\text { Varieties } \\
\text { (A) }\end{array}$} & Shandaweel 3 & 27.73 & 14.23 & 532.60 & 2660.56 & 267.96 & 19.94 & 4.13 & 50.25 \\
\hline & Sohag 1 & 38.39 & 21.14 & 638.97 & 2825.15 & 329.12 & 22.52 & 4.24 & 51.44 \\
\hline \multicolumn{2}{|c|}{$\mathrm{LSD}_{\mathrm{a}}$} & $3.85 * *$ & $1.27 * *$ & $60.14 *$ & NS & 28.88* & $1.23 *$ & NS & $0.77 *$ \\
\hline \multirow{3}{*}{$\begin{array}{l}\text { N levels } \\
\text { (B) } \\
\text { L }\end{array}$} & $40 \mathrm{~kg} \mathrm{fed}^{-1}$ & 29.71 & 16.13 & 555.97 & 2682.65 & 286.22 & 20.63 & 3.99 & 51.37 \\
\hline & $60 \mathrm{~kg} \mathrm{fed}^{-1}$ & 36.41 & 19.25 & 615.59 & 2803.06 & 310.56 & 21.84 & 4.37 & 50.32 \\
\hline & $\mathrm{SD}_{\mathrm{b}}$ & $3.48 * *$ & $1.92 * *$ & 41.91* & NS & 21.53* & $1.12 *$ & $0.25 *$ & $0.79 *$ \\
\hline \multirow{3}{*}{$\begin{array}{l}\text { Micro } \\
\text { Elements } \\
\text { (C) }\end{array}$} & $200 \mathrm{~g} \mathrm{fed}^{-1}$ & 23.17 & 12.60 & 489.81 & 2479.81 & 244.84 & 19.73 & 4.00 & 49.96 \\
\hline & $\begin{array}{l}300 \mathrm{~g} \mathrm{fed}^{-1} \\
400 \mathrm{~g} \mathrm{fed}^{-1}\end{array}$ & & $\begin{array}{l}17.55 \\
22.92\end{array}$ & $\begin{array}{l}586.34 \\
681.20\end{array}$ & & & & & \\
\hline & LSDc & $4.07 * *$ & $2.14 * *$ & $21.91 * *$ & $119.86 * *$ & $11.54 * *$ & & $\mathbf{0 . 0 8} * *$ & $0.40 * *$ \\
\hline Interactions & $\begin{array}{c}\mathrm{AB} \\
\mathrm{AC} \\
\mathrm{BC} \\
\mathrm{ABC} \\
\end{array}$ & $\begin{array}{c}\text { NS } \\
* \\
\text { NS } \\
\text { NS } \\
\end{array}$ & $\begin{array}{c}\mathrm{NS} \\
* \\
\mathrm{NS} \\
\mathrm{NS} \\
\end{array}$ & $\begin{array}{l}\text { NS } \\
\text { NS } \\
\text { NS } \\
\text { NS } \\
\end{array}$ & $\begin{array}{l}\text { NS } \\
\text { NS } \\
\text { NS } \\
\text { NS } \\
\end{array}$ & $\begin{array}{l}\mathrm{NS} \\
\mathrm{NS} \\
\mathrm{NS} \\
\mathrm{NS} \\
\end{array}$ & $\begin{array}{l}\text { NS } \\
\text { NS } \\
\text { NS } \\
\text { NS } \\
\end{array}$ & $\begin{array}{c}* \\
\text { NS } \\
\text { NS } \\
\text { NS } \\
\end{array}$ & $\begin{array}{l}\text { NS } \\
\text { NS } \\
\text { NS } \\
\text { NS } \\
\end{array}$ \\
\hline \multicolumn{10}{|c|}{2014 season } \\
\hline \multirow{3}{*}{\multicolumn{2}{|c|}{$\begin{array}{cc}\begin{array}{c}\text { Varieties } \\
\text { (A) }\end{array} & \text { Shandaweel } 3 \\
& \text { Sohag } 1 \\
\mathrm{LSD}_{\mathrm{a}}\end{array}$}} & 26.60 & 14.09 & 540.69 & 2627 & & & & \\
\hline & & 36.39 & 19.04 & 632.23 & 2884.63 & 324.80 & 21.85 & 4.23 & 51.29 \\
\hline & & 7.74* & $2.83 *$ & 64.44* & 172.90* & 33.86* & $0.99 *$ & NS & $0.28 * *$ \\
\hline \multirow{3}{*}{$\begin{array}{l}\text { N levels } \\
\text { (B) }\end{array}$} & $40 \mathrm{~kg} \mathrm{fed}^{-1}$ & 27.94 & 15.00 & 562.16 & 2661.77 & 290.31 & 21.03 & 3.97 & 51.47 \\
\hline & $60 \mathrm{~kg} \mathrm{fed}^{-1}$ & 35.06 & 18.13 & 610.76 & & 309.03 & 21.33 & 4.35 & 50.45 \\
\hline & $\mathrm{SD}_{\mathrm{b}}$ & NS & NS & $7.76 * *$ & 118.89* & $4.41 * *$ & NS & $0.20 * *$ & $0.21 * *$ \\
\hline \multirow{4}{*}{$\begin{array}{l}\text { Micro } \\
\text { Elements } \\
\text { (C) }\end{array}$} & $200 \mathrm{~g} \mathrm{fed}^{-1}$ & 23.09 & 11.66 & 495.90 & 2530.66 & 245.95 & 19.57 & 3.93 & 49.56 \\
\hline & $300 \mathrm{~g} \mathrm{fed}^{-1}$ & 32.45 & 17.08 & 593.75 & 2773.84 & 304.49 & 21.38 & 4.17 & 51.27 \\
\hline & $400 \mathrm{~g} \mathrm{fed}^{-1}$ & 38.94 & 20.98 & 669.74 & & & 22.59 & 4.37 & 52.05 \\
\hline & SDc & & $0.84 * *$ & $12.53 * *$ & & & & $0.14 * *$ & $0.58 * *$ \\
\hline \multirow{4}{*}{ Interactions } & $\mathrm{AB}$ & NS & NS & $* *$ & NS & $* *$ & NS & NS & $*$ \\
\hline & $\mathrm{AC}$ & $* *$ & $* *$ & NS & & NS & NS & $*$ & NS \\
\hline & $\mathrm{BC}$ & $* *$ & $* *$ & NS & NS & NS & NS & NS & NS \\
\hline & $\mathrm{ABC}$ & NS & NS & NS & $\mathrm{NS}$ & $*$ & NS & $\mathrm{NS}$ & $*$ \\
\hline
\end{tabular}

Fayoum J. Agric. Res. \& Dev., Vol. 29, No.1, January, 2015 
The obtained results are in accordance to those reported by Romemheld and El-Fouly (1999); Heidari et al. (2011); Kohnaward et al. (2012); Hamideldin and Hussein (2014) and Mahdi (2014).

The analysis of variance for sesame yield and its components (Table 3) at different interactions between treatments showed that there were no significant effect in bilateral interactions in both seasons except the effect of interaction (AB) between varieties and $\mathrm{N}$ fertilization levels $(\mathrm{AB})$ on seed index and interaction (AC) between varieties and microelements foliar application (AC) on capsules weight plant ${ }^{-1}$ and seed yield plant ${ }^{-1}$ in 2013 season. The same trend was observed for the significant effect of the interaction (AB) on seed yield $\mathrm{fed}^{-1}$, oil yield $\mathrm{fed}^{-1}$ and oil\%, and the interaction (AC) on capsules weight plant $^{-1}$, seed yield plant ${ }^{-1}$ and seed index. While, the interaction (BC) appeared to be with no significant effect on yield and its components except capsules weight plant $^{-1}$ and seed yield fed ${ }^{-1}$. Sharar et al. (2000), El-Habbasha et al. (2007), Amanullah et al. (2014) and Iarlamen et al. (2014) found that varieties $\mathrm{x} \mathrm{N}$ fertilizer interaction had no significant effect on seed, biological and yields, 1000-seed weight, harvest index and oil \%.

Regarding the triple interaction (ABC) there were no significant effect on yield and its components in 2013 season. Similarly, in 2014 season there were no significant effect of this interaction on yield and its components except its effect on oil yield $\mathrm{fed}^{-1}$ and oil $\%$.

On conclusion, data revealed that the Sohag $1 \mathrm{cv}$ was superior in growth parameters, yield and yield components under the tested treatments. Under the trail conditions it could be recommended that planting Sohag $1 c v$ under applying $60 \mathrm{~kg} \mathrm{~N} \mathrm{fed}{ }^{-1}$ together with $400 \mathrm{~g} \mathrm{fed}^{-1}$ of microelements foliar application is favourable to have profit yield of sesame. 


\section{REFERENCES}

Abid M.; N. Ahmad; M. Jahangir and I. Ahmad (2006). Effect of zinc, iron and manganese on growth and yield of rice (Oryza sativa L.). Pakistan J. Agric., Sci., 39(3): 177-180.

Amanullah J., S. Ali, and M. Ahmad. (2014). Influence of sowing time and nitrogen fertilization on Alternaria leaf blight and oil yield of Sesame cultivars. Pure Appl. Bio., 3(4): 160-166.

A.O.A.C. (1990). Official Methods of Analysis. 15th Ed., Association of Official Agricultural Chemists, Washington, D.C., U.S.A.

Blal, A.E.H.; S.M. Kamel; H.M. Mahfouz and M. Said (2013). Impact of opened, non opened pollination and nitrogen fertilizer on sesame production in the reclaimed land, Ismailia governorate, Egypt. Cercetări Agronomice în Moldova Vol. XLVI , No. 3 (155).

Boghdady, M. S.; Rania M.A. Nassar and F. A. Ahmed (2012). Response of sesame plant (Sesamum orientale L.) to treatments with mineral and bio-fertilizers. Res., J. Agric., \& Bio., Sci., 8(2): 127-137.

Bulletin of Agricultural Statistics. (2013). Arab republic of Egypt, ministry of agriculture and land reclamation, economic affairs sector, summer and nili crops, part (2): P121.

Bulletin Agricultural Statistics. (2014). Arab republic of Egypt, ministry of agriculture and land reclamation, economic affairs sector, summer and nili crops, part (2): P119.

Chen, H.X., F.L. Liu and Y.Z. Zhao (1994). Selection and breeding of Zhong Zhi 9-a new black-seed coated sesame cultivar with superior quality. Oil Crops of China 16: 53-55.

El-Habbasha, S.F.; Abd EI Salam, M.S. and M.O. Kabesh (2007). Response of two sesame varieties (Sesamum indicum L.) to partial replacement of chemical fertilizers by bio-organic fertilizers. Res., J. Agric., \& Bio., Sci., 3(6): 563-571.

El Khier, M.K.S.; K.E.A. Ishag and A.E.A. Yagoub (2008). Chemical composition and oil characteristics of sesame seed cultivars grown in Sudan. Res. J. Agric. Biol. Sci. 4(6): 761-766.

El-Nakhlawy, F. S. and M. A. Shaheen (2009). Response of seed yield, yield components and oil content to the sesame cultivar and nitrogen fertilizer rate diversity. Env. \& Arid Land Agric. Sci., 20(2): 21-31

FAO (2015). Agricultural data FAOSTAT. Food and Agriculture Organization of the United Nations, Rome.

Hamideldin N. and O. S. Hussein (2014). Response of sesame (Sesamum indicum L.) plants to foliar spray with different concentrations of boron. J. Am., Oil Chem., Soc. 91:1949-1953.

Heidari M.; M. Galavi and M. Hassani (2011). Effect of sulfur and iron fertilizers on yield, yield components and nutrient uptake in sesame (Sesamum indicum L.) under water stress. African J. of Biotechnology 10(44): 8816-8822.

Fayoum J. Agric. Res. \& Dev., Vol. 29, No.1, January, 2015 
Iorlamen,T.; F. M. Ayam, and R. A. Akombo (2014). Growth and yield response of sesame (Sesamum indicum L.) to foliar and soil applied fertilizer in Makurdi, Benue State. International Journal of scientific research and management 2(2):528-541.

Ishwar, S.; B.L. Nagda and L.S. Chaudhary (1994). Response of sesame (Sesamum indicum L.) varieties to nitrogen and phosphorus. Ann. Agri. Res. 15: 250-251.

Jakusko, B.B. and B.D. Usman (2013). Effects of NPK fertilizer and plant population density on productivity of sesame (Sesamum indicum L.).Res., J. Agric., \& Enviro., Management 2(5):121-126.

Jadhav, A.S.; G.V. Chavan and D.A. Chavan (1992). Response of summer sesame (Sesamum indicum L.) to nitrogen and phosphorus. Indian J. Agron. 57: 604-605.

Jouyban Z. and S. G. Moosavi (2012). Effect of different irrigation intervals, nitrogen and superabsorbent levels on chlorophyll index, yield and yield components of sesame. J. Food Agric., \& Enviro., 10 (1): 360364.

Kassab, O.M.; H.M. Mehanna and A. Aboelill (2012). Drought impact on growth and yield of some sesame varieties. J. Applied Sci., Res., 8(8): 4544-4551.

Kohnaward P., J. Jalilian and A. Pirzad (2012). Effect of foliar application of Micro-nutrients on yield and yield components of safflower under conventional and ecological cropping systems. International Res., J. Applied \& Basic Sci., 3 (7):1460-1469.

Mahdi, A. S. (2014). Effect of foliar application with iron and zinc on growth and yield of sesame. The Iraqi J. Agric., Sci., 45(1): 18-25.

Malik, M.A., O.H. Arugh and M. Ramzan (1990). Effect of row spacings and fertility levels on quantity and quality of Sesamum indicum L. J. Agri. Res. 30: 213-218.

Mankar, D.D., R.N. Satao, V.M. Solanke and P.G. Ingole (1995). Effect of nitrogen and phosphorus on quality, uptake and yield of sesame. PKV Res. J. 19: 69-70.

Noorka, I. R.; S.I. Hafiz and M. A. S. El-Bramawy (2011). Response of sesame to population densities and nitrogen fertilization on newly reclaimed sandy soils. Pakistan J. Bot. 43(4): 1953-1958.

Osman, H.E. (1993). Response of sesame cultivars to plant density and nitrogen in the Sudan central rainlands. Arab Gulf J. Sci. Res. 11: 365-76.

Pawar, P.R., R.A. Patil, S.A. Khanvilkar, U.V. Mahadkar and S.B. Bhagat (1993). Effects of different levels of nitrogen and phosphorus on yield and quality of sesame. J. Maharashtra Agri. Univ. 18: 310-311.

Purushottam G. (2005). Integrated nutrient management in sesame (Sesamum indicum L.) and its residual effect in succeeding chickpea (Cicer arietinum L.). M.Sc thesis, University of Agricultural Sciences, Dharwad, India, $100 \mathrm{pp}$.

Fayoum J. Agric. Res. \& Dev., Vol. 29, No.1, January, 2015 
SESAME VARIETAL RESPONSE TO MICROELEMENTS.

Romemheld V. and M.M. El-Fouly (1999). Foliar nutrient application Challenge and limits in crop production. Proceedings of the 2nd International Workshop on Foliar Fertilization, Bangkok, Thailand, 4-10 April 1999.

Sharar , M.S.; M. Ayub,; M.A. Choudhry and M. Asif (2000). Growth and yield of sesame genotypes as influenced by NP application. international J. of Agric., Biol. 2(1-2):86-88.

Shehu H. E1.; J. D. Kwari and M. K. Sandabe (2010). Nitrogen, phosphorus and potassium nutrition of sesame (Sesamum indicum) in Mubi, Nigeria. New York Sci., J. 3(12):21-27.

Shinde, Y.M., P.N. Chaudhari, A.B. Deokar and P.L. Badhe (1994). Padmaa new variety of sesame for a part of Maharashtra. J. Maharashtra Agri. Univ. 19: 190-191.

Sinharoy, A., R.C. Samui, M.M. Ahsan and B. Roy (1990). Effect of different sources and levels of nitrogen on yield and yield attributes of sesame cultivars. Environ., and Ecology,8:211-215.

Snedecor, G.W. and W.G. Cochran, (1990). Statistical Methods. $8^{\text {th }}$ Ed., Iowa state Univ., Press, Ames, Iowa, U.S.A.

Wilde S.A; R.B. Corey; J.G. Lyer and G.K. Voigt (1985). Soil and Plant Analysis for Tree Culture. $3^{\text {rd }}$ Edition. Oxford and IBM Publishers, New Delhi, India. 93-106.

Zebib, H.; G. Bultosa and S. Abera (2015). Physico-chemical properties of sesame (Sesamum indicum L.) varieties grown in northern area, Ethiopia. Agricultural Sciences (6): 238-246.

Zeidan M.S.; Manal F. Mohamed and H.A. Hamouda (2010). Effect of Foliar fertilization of $\mathrm{Fe}, \mathrm{Mn}$ and $\mathrm{Zn}$ on wheat yield and quality in low sandy soils fertility. World J. Agric., Sci., 6 (6): 696-699.

Fayoum J. Agric. Res. \& Dev., Vol. 29, No.1, January, 2015 


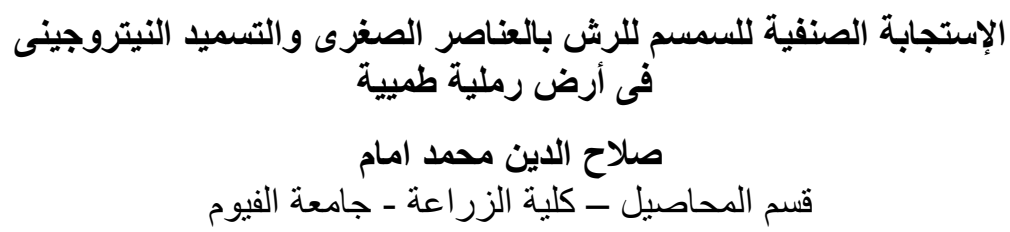

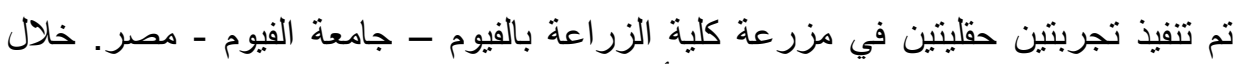

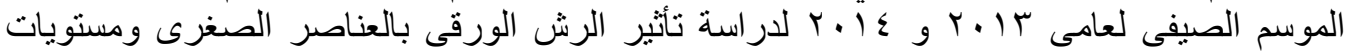

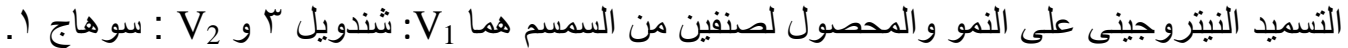

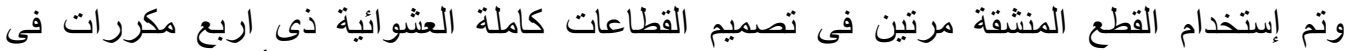

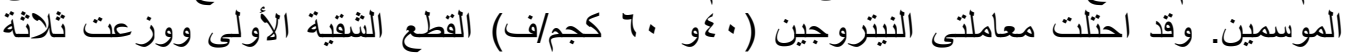

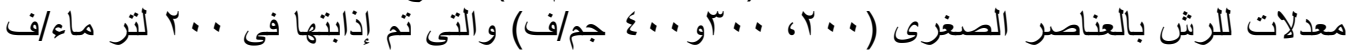

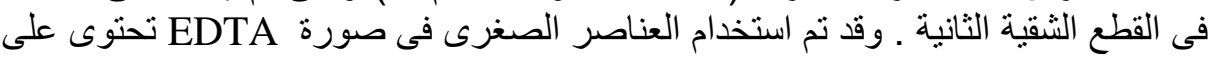

(Fe 7.5 \%, Mn 3.5 \%, Zn 0.70 \%, Cu 0.28 \%, B $0.65 \%$ and Mo $0.30 \%$ w/w)

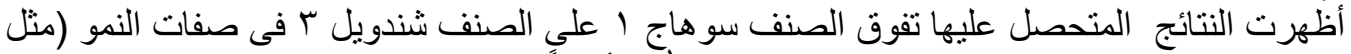

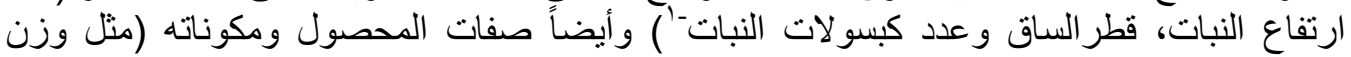

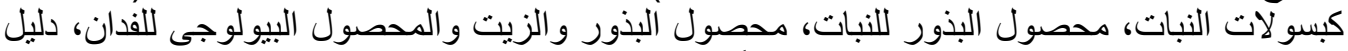

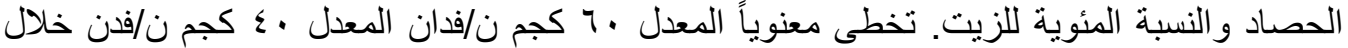

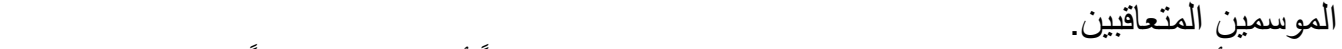
أعطى المعدل . . عجم / فدان من العناصر الصغرى رشاً أعلى القيم معنوياً لكل الصفات خلال

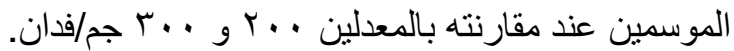

